UDK 372.881.111.1
DOI 10.33251/2522-1477-2019-5-86-89
HERASYMENKO Liudmyla,

Candidate of Pedagogical Sciences, Associate Professor, Associate Professor of Foreign Languages Department, Flight Academy of National Aviation University

\section{MURAVSKA Svitlana,}

Candidate of Pedagogical Sciences,

Associate Professor of Foreign Languages Department, Flight Academy of National Aviation University

\title{
A CASE STUDY: A TOOL FOR DEVELOPING CRITICAL THINKING SKILLS OF MANAGEMENT STUDENTS
}

The article reveals the problem of developing critical thinking skills for future managers in higher educational establishments. It is emphasized that analyzing the situation, synthesizing or evaluating information, observation, applying experience, reflection, reasoning and communication are the key competencies for today's education. Critical thinking is considered as the process of determining the authenticity, accuracy, or value of something. It is characterized by the ability to seek reasons and alternatives, perceive the total situation, and change one's view based on evidence. The article gave the example of using a case study as an effective technique for developing critical thinking of management students. The main advantage of case studies is encouraging future managers to think, analyze, apply, evaluate and take the right decision.

Key words: critical thinking skills, management students, teaching English for specific purposes, case study, professional education.

Introduction. Critical thinking is a highly debated topic today. In the past teachers gave to pupils or students a certain amount of material which they had to learn at home. We are living in the era of fast development of the Internet and computer technologies. Students graduate from the university with knowledge which will not be applicable tomorrow. Therefore, teachers need to focus on developing students' critical thinking. They should be able to find solutions, perform certain tasks and be ready to be involved in non-stop process of developing their critical thinking skills. Such skills are necessary for analyzing the situation, synthesizing or evaluating information, observation, applying experience, reflection, reasoning and communication.

Children are not born with critical thinking skills, they need to be taught. It is good if at schools teachers concentrate on developing critical thinking. When children come to higher educational establishments, this process must be continued. Critical thinking skills are of utmost importance for management students as they need to organize work effectively, delegate the tasks and motivate the staff. The education as well as the market scenario is changing very fast. A decade ago, those managers who had a brilliant academic record were well hired after by most of the corporate institutions. But today knowledge is not sufficient enough for work in the corporate world. Employers prefer to hire and promote those persons who have developed critical thinking skills.

There are many techniques for developing critical thinking skills in the English language classrooms and a case study is one of them. Becides, it encourages teamwork and accountability, and is realistic and motivating to adult learners to be engaged in their learning to think about plausible answers instead of passively receiving the information. We should have a look at how this method works in reality.

Review of recent sources of research and publications. Critical thinking has been a focus of research of many educators and scientists (J. Alvino, B. Bloom, R. Ennis, K. Meredith, B. Moore \& R. Parker, W. Paul, J. Steel, Ch. Temple, S. Walter, etc.). In their papers researchers tried to give a definition to critical thinking, define its characteristics and ways of developing critical thinking skills.

Setting an objective. The objective of the article is to demonstrate how a case study can be used for developing critical thinking skills of management students.

Presentation of basic material. Many researchers point out to the fact that it is difficult for a child to develop such a complex ability as critical thinking without any additional aids from the side of a 
teacher. For example, G. Nosich [4] holds that most scholars believe that skills needed to begin to think about issues and problems do not suddenly appear in our students. Teachers who have attempted to incorporate higher level questioning in their discussions or have administered test items demanding some thought rather than just recall from their students are usually dismayed at the preliminary results. Unless the students have been prepared for the change in expectations, both the students and the teacher are likely to experience frustration. Therefore, we understand that teachers play a vital role in this process, particularly in a language classroom where pupils or students get a chance to express themselves and evaluate the arguments of their group mates.

I.Wright says "when I discovered critical thinking, my teaching changed" [7, p. 9]. He notes that instead of focusing on questions which had "right" answers, he wanted children to think through situations where the answer was in doubt. He believes that critical thinking is beneficial in social studies along with music, in science when dealing with environmental problems, deciding whether animals should be used in research, or figuring out the best way to test a hypothesis, in literature study during judging the actions of characters in stories, and in all subject areas when deciding which sources of information were most reliable or how best to present information.

First of all, it is necessary to discuss the notion of critical thinking in more details. R. Fisher notes that "Critical thinking describes how something is being thought about" [4, p. 65]. He adds that learning to think critically means: a) learning how to question, when to question and what questions to ask, and b) learning how to reason, when to use reasoning and what reasoning methods to use. Finally he mentions that being a critical thinker one should develop certain attitudes, such as a desire to reason, willingness to challenge and a passion for truth.

D. Moseley [5] stated that "thinking skills" means expertness, practical ability or facility in the processes of thinking, such as remembering, forming concepts, planning what to do and say, imaging situations, reasoning, solving problems, considering opinions, making decisions and judgments, and generating new perspectives.

J. Alvino, in his "Glossary of Thinking-Skills Terms", offers a set of definitions which are widely - though not universally - accepted by theorists and program developers. They include [1, p. 50]:

- BLOOM'S TAXONOMY. Popular instructional model developed by the prominent educator Benjamin Bloom. It categorizes thinking skills from the concrete to the abstract - knowledge, comprehension, application, analysis, synthesis, evaluation. The last three are considered HIGHERORDER skills.

- COGNITION. The mental operations involved in thinking; the biological/neurological processes of the brain that facilitate thought.

- CREATIVE THINKING. A novel way of seeing or doing things that is characterized by four components - FLUENCY (generating many ideas), FLEXIBILITY (shifting perspective easily), ORIGINALITY (conceiving of something new), and ELABORATION (building on other ideas).

- CRITICAL THINKING. The process of determining the authenticity, accuracy, or value of something; characterized by the ability to seek reasons and alternatives, perceive the total situation, and change one's view based on evidence. Also called "logical" thinking and "analytical" thinking.

- INFUSION. Integrating thinking skills instruction into the regular curriculum; infused programs are commonly contrasted to SEPARATE programs, which teach thinking skills as a curriculum in itself.

- METACOGNITION. The process of planning, assessing, and monitoring one's own thinking; the pinnacle of mental functioning.

- THINKING SKILLS. The set of basic and advanced skills and subskills that govern a person's mental processes. These skills consist of knowledge, dispositions, and cognitive and metacognitive operations.

- TRANSFER. The ability to apply thinking skills taught separately to any subject.

It has already been mentioned that critical thinking should be taught at higher educational establishments. It is a very important issue for management students who are supposed to work in tourism industry and aviation sphere after graduation.

The curriculum presupposes using Market Leader Course Book (Pre-intermediate and Intermediate), Practice File, Audio and Test Bank [2;3]. Each unit in this book focuses on development all 
language skills: listening, speaking, reading and writing. At the end of each unit there is a case study section which is an ideal option for developing critical thinking for a few reasons. Firstly, working with a case study management students learn to analyze and synthesize information. Secondly, they should apply this information to take the right decision. In the process of discussion students listen to their group mates' point of view, evaluate it and take the information which they agree to. Finishing a case study section, students are required to come to a conclusion and in a logical form present all the points in a letter or any other official document. So, as we can see a case study encourages our students to think, find solutions, give reasoning, and take part in discussions or debates. One more important point here is the fact that only authentic materials are used in this book, in such a way broadening students' world outlook and improving their language competency.

Let's have a look in more details at the example of a case study. The first unit in Market Leader Intermediate [2] is called Brands. A case study in the first unit is devoted to Hudson Corporation, a luxury luggage manufacturer. The problem is that this company is facing increased competition from cheaper imports. It must decide how to protect its brand and create new markets for its products.

The first step is reading and analyzing background information. A special attention should be paid to results of market research. Hudson recently set up a series of focus groups to find out how consumers perceived the company's brand in the USA.

The second step is listening comprehension. Four of Hudson's American managers are talking about the problems they could face in Europe. The students should listen and make notes on the key points.

Next step is discussing marketing strategies for Europe, such as Reposition the brand, Develop the Hudson brand, Hire a top designer, Develop a wider product range, Stretch the Hudson brand, Develop sales using e-commerce. Students are required to work in small groups as directors of the Hudson Corporation. They need to hold an informal meeting, consider the advantages and disadvantages of each option listed above. The participants of the meeting should choose two of the marketing strategies which Hudson should focus on to expand sales in European markets.

After that the students should meet as one group and decide which two marketing strategies they will use to develop sales in European markets.

The final stage in a case study section is writing. As the CEO of Hudson Corporation students need to write an e-mail to the head of European Marketing Associates, David Wright, summarizing the actions they agreed to take at the meeting with their reasons. They are also to suggest a time for a meeting with David Wright and his associates.

Conclusion. Recently there has been increased emphasis on the development of management students' critical thinking skills, including problem-solving and analytical skills. Such skills are enhanced through the adoption of the case study method. English is an ideal choice as the teachers have a wide range of techniques and materials to do this. The inclusion of case studies in English curriculum represents 'real world' situations and gives students possibility to develop the key competences for future. It encourages them to think, analyze, apply, evaluate and take the right decision.

\section{References}

1. Alvino, J. (1990). A glossary of thinking-skills terms. Learning. No 18 (6). P. 6-50.

2. Cotton, D., Kent S., Falvey, D. (2010). Market Leader 3rd Edition Intermediate Business English Course book with DVD-rom. Pearson-Longman.

3. Cotton, D., Kent, S., Falvey, D. (2010). Market Leader 3rd edition intermediate Business English Teacher's Resource Book. Pearson-Longman.

4. Fisher, R. (1990). Teaching children to think: London: Nelson Thorns Ltd.

5. Moseley, D., Baumfield, V., Higgins, S., Lin, M., Miller, J., Newton, D., and Robson, S. (2004). Thinking skill frameworks for post-16 learners: an evaluation. Learning and skills Research Center, Newcastle University.

6. Nosich, G. (2001). Learning to think things through: A guide to critical thinking in the curriculum. Upper Saddle River, NJ: Prentice-Hall.

7. Wright, I. (2002). Is that right?: Critical thinking and the social world of the young learner. Ontario, Canada: Pippin Publishing Corporation. 


\section{Список використаних джерел}

1. Alvino, J. (1990). A glossary of thinking-skills terms. Learning. No 18 (6). P. 6-50.

2. Cotton, D., Kent S., Falvey, D. (2010). Market Leader 3rd Edition Intermediate Business English Course book with DVD-rom. Pearson-Longman.

3. Cotton, D., Kent, S., Falvey, D. (2010). Market Leader 3rd edition intermediate Business English Teacher's Resource Book. Pearson-Longman.

4. Fisher, R. (1990). Teaching children to think: London: Nelson Thorns Ltd.

5. Moseley, D., Baumfield, V., Higgins, S., Lin, M., Miller, J., Newton, D., and Robson, S. (2004). Thinking skill frameworks for post-16 learners: an evaluation. Learning and skills Research Center, Newcastle University.

6. Nosich, G. (2001). Learning to think things through: A guide to critical thinking in the curriculum. Upper Saddle River, NJ: Prentice-Hall.

7. Wright, I. (2002). Is that right?: Critical thinking and the social world of the young learner. Ontario, Canada: Pippin Publishing Corporation.

ГЕРАСИМЕНКО Людмила Сергіївна, кандидат педагогічних наук, доцент, доцент кафедри іноземних мов, Льотна академія Національного авіаційного університету;

МУРАВСБКА Світлана Миколаївна, кандидат педагогічних наук, доцент кафедри іноземних мов, Льотна академія Національного авіаційного університету.

\section{КЕЙС-СТАДІ: ІНСТРУМЕНТ ДЛЯ РОЗВИТКУ УМІНЬ КРИТИЧНОГО МИСЛЕННЯ СТУДЕНТІВ-МЕНЕДЖЕРІВ}

Анотація. Стаття присвячена проблемі розвитку умінь критичного мислення майбутніх менеджерів у вищих навчальних закладах. Підкреслюється, щчо аналіз ситуації, синтез або оцінка інформаџіï, спостереження, застосування досвіду, рефлексія, обтрунтування та комунікація є ключовими компетенціями для освіти сьогодення. Критичне мислення розглядається як прочес визначення достовірності, правильності або цінності чогось. Воно характеризується здатністю шукати причини та альтернативи, сприймати загальну ситуацію й змінювати свою позицію на основі доказів. У статті наведено приклад використання кейс-стаді як ефективного методу розвитку критичного мислення студентів-менеджерів. Головною перевагою кейс-стаді є заохочення майбутніх менеджерів до мислення, аналізу, застосування на практиці, оцінки та прийняття правильного рішення.

Ключові слова: уміння критичного мислення, студенти менеджери, викладання англійськой мови для конкретних ичілей, кейс-стаді, професійна освіта.

Одержано редакиією: 26.02.2019 p. Прийнято до публікаиї: 13.03.2019 p. 